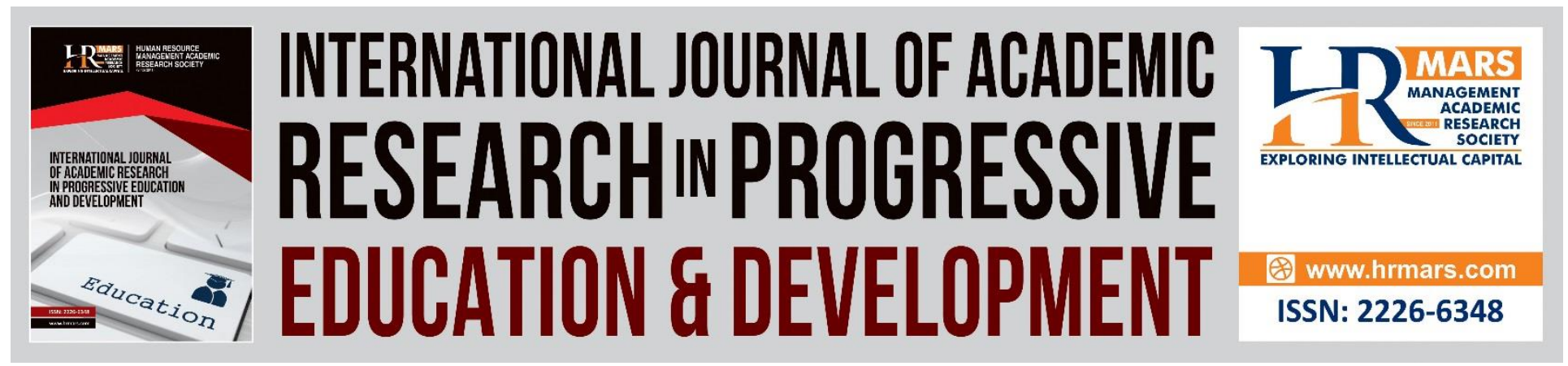

\title{
Problems in Writing Scholarly Articles in English among Indonesian EFL Post-Graduate Students
}

Nadella Lesmana, Kamisah Ariffin

To Link this Article: http://dx.doi.org/10.6007/IJARPED/v9-i4/8174

DOI:10.6007/IJARPED/v9-i4/8174

Received: 11 October 2020, Revised: 13 November 2020, Accepted: 16 December 2020

Published Online: 29 December 2020

In-Text Citation: (Lesmana \& Ariffin, 2020)

To Cite this Article: Lesmana, N., \& Ariffin, K. (2020). Problems in Writing Scholarly Articles in English among Indonesian EFL Post-Graduate Students. International Journal of Academic Research in Progressive Education and Development, 9(4), 12-24.

Copyright: (C) 2020 The Author(s)

Published by Human Resource Management Academic Research Society (www.hrmars.com)

This article is published under the Creative Commons Attribution (CC BY 4.0) license. Anyone may reproduce, distribute, translate and create derivative works of this article (for both commercial and non-commercial purposes), subject to full attribution to the original publication and authors. The full terms of this license may be seen at: http://creativecommons.org/licences/by/4.0/legalcode

Vol. 9 (4) 2020, Pg. 12 - 24

http://hrmars.com/index.php/pages/detail/IJARPED

JOURNAL HOMEPAGE

Full Terms \& Conditions of access and use can be found at http://hrmars.com/index.php/pages/detail/publication-ethics 


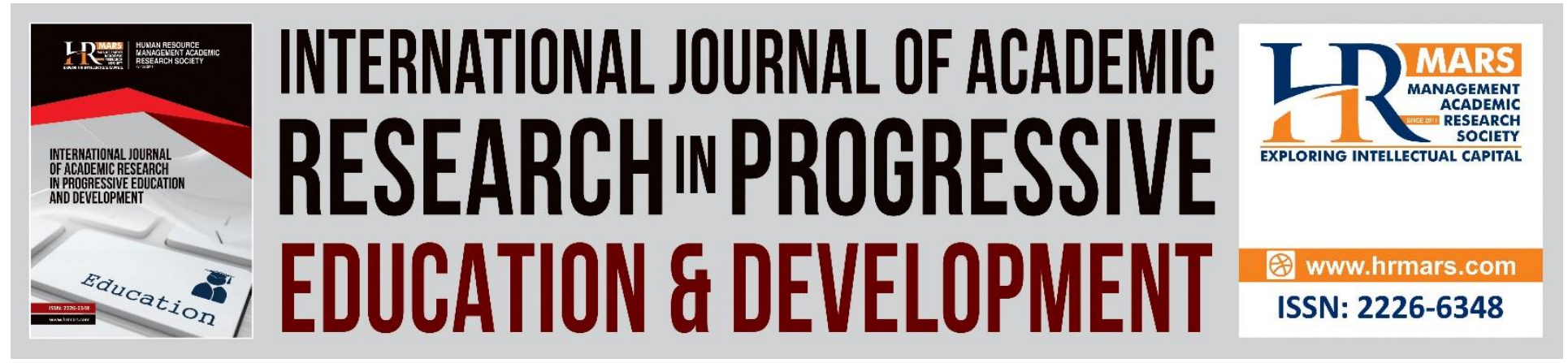

\title{
Problems in Writing Scholarly Articles in English among Indonesian EFL Post-Graduate Students
}

\author{
Nadella Lesmana ${ }^{1}$, Kamisah Ariffin ${ }^{2}$ \\ ${ }^{1}$ Faculty of English Language Teaching Universitas Ahmad Dahlan, Yogyakarta, Indonesia, \\ ${ }^{2}$ Academy of Language Studies Universiti Teknologi MARA Cawangan Pahang, Malaysia \\ Email: nadella.lesmana.18@gmail.com, kamisah@uitm.edu.my
}

\begin{abstract}
The directive from the Indonesian Directorate General of Institutional Science, Technology, and Higher Education that graduates from the universities in Indonesia must publish at least one scholarly article in English as a prerequisite to complete their study is seen as a move towards upgrading the quality and the credential of graduates in the country. However, for EFL students, this is not an easy task. This study aimed at examining the problems faced by the post-graduate students in Indonesia in writing scholarly articles in English and to identify the support needed by these students to enhance their writing skills. Using survey questionnaire and interview as methods of data collection, the findings indicate that the participants faced challenges from the cognitive, linguistic, psychological, and external factors aspects. The participants also informed of the institutional, pedagogical and social support needed to assist them in producing quality scholarly writings.
\end{abstract}

Keywords: Challenges, Scholarly Writing, EFL Students.

\section{Introduction}

Scholarly writing, or academic writing as it is often known, is significant in the academic world. It may take a number of different forms such as essays, journal articles, research reports and theses. These writings serve as a tool to communicate acquired knowledge in a specific field of study. The main objective of a scholarly writing is to prove a thesis and to convince readers that the author's thesis statement is valid. This requires strong techniques in conveying ideas which include analyzing, conveying understanding, thinking critically and writing style. An academic, thus, should be well-versed with the genre of academic writing as it varies from other types of writing in terms of structure and style. It has to be organized and planned with precision and accuracy. As put forward by Glatthorn (1998), academic writing should be written in a style that strives for clarity, maturity, and formality, striking a balance between confidence and tentativeness. 
In the academic world, the English language has been the predominant choice for many local and international scholarly journals. This is because, not only English is considered as a language of prestige and status, it also indicates a sign of a good quality of education. It has, thus, become the language of the business and scientific world, and the global academic language that facilitates the international mobility of young researchers (Graddol, 2006). Thus, producing scholarly writings in English is clear. It can project one's research worldwide, have more chances of gaining potential readers and maintain a high level of academic positions. The directive from the Indonesian Directorate General of Institutional Science, Technology, and Higher Education that graduates from the universities in Indonesia must publish at least one academic article in English as a prerequisite to complete their study is seen as a move towards upgrading the quality and the credential of graduates in the country.

However, for EFL students in a non-English speaking country, the mandatory task of producing and publishing English scholarly writing is not easy. For some students, it may be difficult, daunting and stressful. This is because writing for publication is more than just writing a good course paper (Nolan \& Rocco, 2009). Not only they have to deal with the technicalities of academic writing, the students also have to meet a certain level of fluency and accuracy in order to produce publishable articles.

English is widely considered and predominantly used for writing academic or scientific research papers

/work. English has been the language of choice for many international scholarly journals.

There have been local studies that show EFL Indonesian students are struggling in their academic writing (Ariyanti \& Fitriana, 2017; Padmadewi, 2016; Yaqin, 2015; Wigati (2015). However, most of these studies examined the students' problems in their academic writing based on their writing products. The writers feel that it is important to find out the problems from the students' point of view so that assistance can be provided more objectively based on their needs. Thus, this present study investigates the challenges faced by the students and the supports they need to assist them in producing publishable articles in English.

\section{Literature Review}

Scholarly writing in English is by no means an easy task for EFL learners. This is because scholarly writing has its own set of rules that involve style, tone, language use and organisation. Even for most native English speakers, scholarly writing poses quite a challenge (Al Fadda, 2012) as it requires proper planning as it has to be explicit, factual, objective and analytical. Rao (2018, p. 1), put forward that scholarly writing is 'complex, formal, objective, explicit, hedged and responsible'.

Studies have reported that problems faced by EFL learners are commonly related to language skills such as low mastery level of grammar, structure and vocabulary, discourse such as low level of basic academic writing skills, psychology such as attitude, anxiety and lack of motivation, and teaching environment such as lack of attention and inappropriate teaching method. Studies done by Khan (2011); Al Mubarak (2017) and Akbari (2015) indicate that the obstacles to academic 
writing in English among Saudi, Sudanese and Egyptian EFL students were language-related. These studies found that the learners faced difficulties in various aspects of language such as grammar, structure and mechanics of writing. Similar findings were also reported in Jafari and Ansari's (2012); Huwari and Al-Khasawneh's (2013) and Bani Younes and Salamh Albalawi's (2015) studies that students mostly encountered problems that are related to language in their academic writing. These included problems in grammar, vocabulary and sentence structure. Other lines of enquiry show that learners were also confronted with problems of content, organisation, idea development and cohesion in their writing (Yuen \& Mussa, 2015; Mustaque, 2014; Al Seyabi \& Tuzlukova, 2014; Hammad, 2016).

Khan (2011) reported that the learners' writing problems can be attributed to an array of factors ranging from the lack of English language curriculum, unfavourable teaching methods, inappropriate language environments and lack of personal motivations on the learners' part. Along the same line, Jafari and Ansari (2012) attributed the learners' writing problems to various factors like learners' lack of motivation, low English proficiency, low level of vocabulary, L1 interference and anxiety. Jabali (2018) also confirmed that learners' attitudes or perceptions toward the writing process and writing difficulties could also add up to the problems encountered in academic writing.

In the local Indonesian scene, studies that looked into problems in writing academic papers among EFL learners are quite replete (Wigati, 2015; Padmadewi, 2016; Ariyanti, 2016; Ariyanti \& Fitriana, 2017). The findings of these studies mostly concur with those of the empirical studies. However, most of the problems faced by the learners in their academic writing were identified based on the analysis of the product of their writing. The present study investigates the issue from the learners' perspectives based on a framework developed from the empirical findings which is depicted in the following figure:

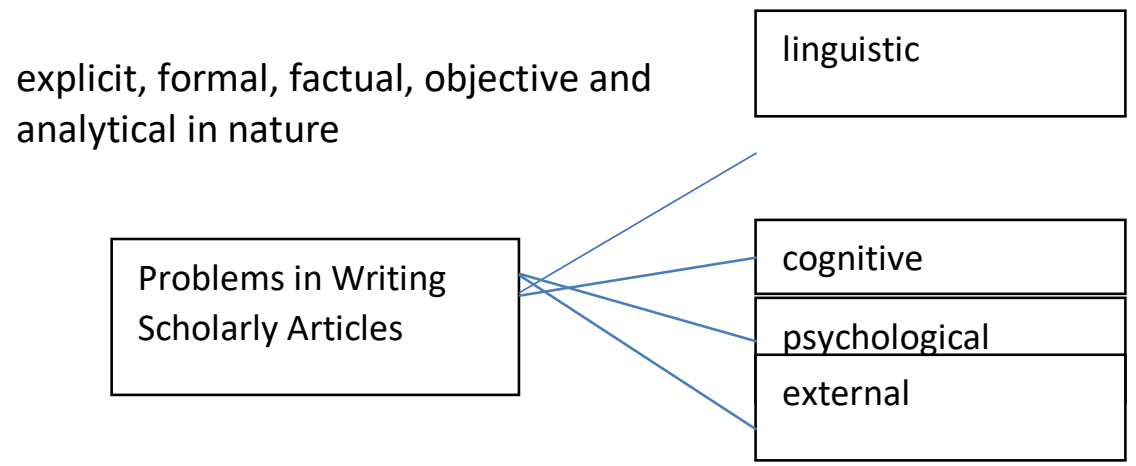

Figure 1: Framework for Investigation

The investigation of the students' problems in writing scholarly articles was examined under four aspects: i) language skills, ii) cognitive skills, iii) psychological factors, and iv) external factors. The language aspect looked into language-related capabilities of the students which included grammar knowledge, vocabulary, mechanics of writing and sentence structure. The cognitive aspect examined the students' abilities in writing scholarly articles in terms of content, cohesion, 
idea development and organization. The next aspect gauged the students' problems from the psychological perspectives such as motivation, anxiety and attitude. Lastly, the external factors dealt with issues including pedagogy and support from the institution.

\section{Objectives}

The main objective of this study was to investigate the problems confronting the Indonesian EFL students at the Graduate School, Universitas Ahmad Dahlan in writing scholarly articles in English. It also aimed at identifying the supports needed by the students to facilitate their scholarly writing in English. Thus, the research questions can best be expressed as follows:

1. What are the problems confronting the EFL students at the School of Universitas Ahmad Dahlan in writing scholarly articles in English?

2. What are the supports needed by the students to facilitate their scholarly writing in English?

\section{Methodology}

This study employed a mixed method of quantitative and qualitative approaches for data collection and analysis. It also used the explanatory model of the mixed methods research design to provide better understanding and explanation of the study in question.

The participants of this study were the students at the Graduate School of Universitas Ahmad Dahlan, Yogyakarta, Indonesia. Initially, all students from the schools of education, science, technical and humanities were invited to take part in the study. However, due to the COVID-19 pandemic, the time when this study took place, only 72 students responded positively to the invitation. A survey, using online questionnaires, was used to obtain quantitative data. The questionnaires were distributed to the participants via email. However, only 53 were returned, of which 50 were usable as 3 were incomplete. The qualitative data were collected from phone and whatsapp interviews involving 10 participants.

The questionnaire was developed based on the framework set for the study. It contained 6 sections. Section A contained close-ended questions that gauged the demographic background of the participants. Sections B, C, D, and E contained statements on 5-Lickert scale that probed into the participants' opinion under the four aspects: linguistic, cognitive, psychological and external. Section F contained statements on 5-Lickert scale that examined the support needed by the participants in their writing. The questionnaire was first piloted for reliability using the Cronbach Alpha set at 0.6. The results show high reliability with alpha value of $0.986>0.6$.

Online interviews using whatsapp video call were carried out to gauge the respondents' personal experience, feelings and attitude towards writing scholarly articles. A list of interview questions based on the framework of investigation was used as a guideline. Additional questions were added impromptu based on the responses. Each interview session took about 10-15 minutes. The sessions were recorded and later transcribed. 
Data from the questionnaire were treated quantitatively and analysed using SPSS version 20.0. The data on the demographic background of the participants were analysed based on the frequency counts. As for the problems faced in scholarly writing, the cumulative mean score was used to determine the ranking of the problems in the framework of investigation. On the other hand, data from the interview were qualitatively reported based on the respondents' account of their problems in writing scholarly articles. These were used to support the quantitative findings from the questionnaire.

\section{Findings and Discussion}

Demographic Background of the Participants

Of the 50 participants, 29 were from the Faculty of Education, 10 were from Faculty of Science and 11 were from the Faculty of Social Sciences and Humanities. The data indicate that all of them had received formal English language education between $9-11$ years. However, to them English was very much of a foreign language as it was mostly heard and used in the English class. Their mother tongue varied from Javanese, Lampungnese, Bimanese, Sampitnese, Lomboknese and many other regional languages. The national language, Indonesian, was used in almost every aspect of their oral and written communication. The participants disclosed that their English language proficiency was between low and moderate levels as they seldom used the language in their daily life.

With regards to publishing scholarly articles in journals, half of the participants claimed that they had published at least one article in English. However, it was only at national level and the article was written with the help of their lecturers or supervisors. When asked whether they were able to write an article on their own, only ten of them claimed that they could do so but they would ask their lecturers (who were the co-authors) to go through the article before submitting it to a journal.

All of the participants had had some knowledge of writing scholarly articles as they had taken the academic writing course offered by the university. All of them agreed that while the course had been helpful, they felt that it was inadequate and they needed further personal guidance in writing scholarly articles.

\section{Problems in Writing Scholarly Articles}

The study investigated the respondents' problems in writing scholarly articles under four aspects: linguistic, cognitive, psychological and external. Table 1 depicts the ranking of the problems faced by the respondents. 
INTERNATIONAL JOURNAL OF ACADEMIC RESEARCH IN PROGRESSIVE EDUCATION AND DEVELOPMENT

Vol. 9, No. 4, 2020, E-ISSN: $2226-6348$ @ 2020 HRMARS

Table 1: Problems in Writing Scholarly Articles

\begin{tabular}{lll}
\hline No & Aspect & Mean \\
\hline 1 & Cognitive & 4.15 \\
\hline 2 & Linguistic & 3.83 \\
\hline 3 & External & 3.60 \\
\hline 4 & Psychological & 3.58 \\
\hline
\end{tabular}

Despite having the training in academic writing, all 50 of the participants claimed that they still faced problems in all aspects of investigation. The data indicate that there is not much difference in the mean value between the aspects. As can be seen from Table 1, the most difficult aspect in scholarly writing according to the respondents was the cognitive-related dimension (mean=4.15). This is followed by language-related and external aspects (mean $=3.83$ and 3.60 respectively). The least difficult aspect, with a difference of 0.02 mean score from the external factors, was psychological (mean=3.58).

\section{Cognitive Aspect}

The cognitive skills needed in writing scholarly articles include organizing ideas and content, writing cohesively, and observing the style or the norms of the genre like vocabulary and language phrases. Data from the questionnaire indicate that problems in organizing ideas and content top the list (mean=4.56).

The respondents claimed that they did not know how to organize ideas the way scholarly articles are written. For example, they did know how to introduce the background of the study and lead it to thesis of the article. The data also reveal that more than half of the respondents had problems in writing the main idea and major supporting details. This is supported by the interview data that disclosed 38 or $76 \%$ of the participants were not aware the structure of a scholarly article and the contents that go with each section. Such problem, hence, leads to another problem, which is cohesion and coherence in their writing. The respondents reported that they sometimes had problems in linking the main idea with the major and minor ideas when putting forward the claim. This is in line with Faradhibah's (2017) study on the coherence and cohesion in students' ESL writing. She found that students had problems in maintaining coherence and cohesion because they had difficulties in determining and stating the ideas, fulfilling the supporting details, using the proper transition signals and spelling and punctuation. Along the same line, Al-Zubeiry (2020) in his study on Arab EFL students' writing found that the problems of coherence were also ascribed to the students' inability to substantiate their main idea with relevant supporting details, and the failure to use conjunctions, references and lexical items that link sentences correctly and appropriately.

Another difficulty that needs serious attention is the respondents' lack of familiarity with conventions of scholarly writing. Although all the respondents claimed that they were aware that writing for academic purposes is different from writing for general purposes, 38 or $76 \%$ did not really know the make-up of this type of writing. They were not familiar with the style, tone and registers used in this writing. 32 or $64 \%$ of the respondents claimed they were weak at 
paraphrasing and 3 or $6 \%$ were not sure how to paraphrase. This concurs with Ankawi's (2015) report on Saudi students' difficulties in their academic writing because they had problems in understanding academic writing conventions. This is due to their lack of skills in paraphrasing and summarizing, sufficient academic writing vocabulary and critical thinking. This corresponds with Manjeet (2016) who also claimed that ESL students had difficulty in adhering to proper academic writing techniques.

\section{Linguistic Aspect}

Another problem faced by the respondents in this study is language-related. All of the respondents marked problems in grammar, sentence structure and vocabulary as the hindrance to producing good scholarly writing. Among the major language problems cited by the respondents were tenses (mean=4.21), sentence structure (mean=4.18, and vocabulary (mean=3.96). The respondents claimed that due to their limited English vocabulary and grammar, they were unable to convey their ideas well, thus, affecting the quality and content of their writing. This is in concordance with previous studies that a deterrent to good writing among ESL/EFL learners is grammatical inaccuracy, resulting from low English proficiency at the word or sentence level. For example, Al-Khasawneh (2010) put forward that a reasonable vocabulary size is needed for the students to write effectively and to convey accurate messages in their academic writing. Similarly, Abdulkareem (2013) and Alfaki (2015) also found that grammar and sentence structure posed serious problems to effective academic writing among EFL students in addition to word choice.

It is interesting to note that 12 students from the Faculty of Education who were majoring in English also claimed that even though they were taking English courses, and they were supposed to be proficient in the language, they still faced problems in grammar and vocabulary writing. This is because the language input that they received mostly was from classes attended. The absence of the language in their surroundings outside classroom hours could sometimes be erased from the memory. Thus, writing sentences with the correct structure and grammar would still be a challenge for them.

Mother tongue or L1 interference can be one of the reasons for the participants' problems in mastering the English language grammar, hence, having effects on their writing. When asked about their strategies in writing an article, 38 or $76 \%$ of the participants admitted that they at times, would think either in Bahasa Indonesia or their L1 first, then, translate the sentences or paragraphs into English. As they translated their thoughts in the L1 into English, it would cause both interlingual and intralingual errors in their writing. Other studies have shown that EFL learners commit errors because they think in their native language and that they translate their thoughts into the L2 or foreign language (Khuwaaileh \& Al-Shoumali, 2000; Ab Manan, Zamari, Pillay, Adnan, Yusof, et al., 2017).

\section{External Factors}

Students' ability or disability to write good scholarly article may also be influenced by external factors like learning environment that include support provided by the institution and guidance 
from instructors. 100\% of the respondents agreed that the university had provided support to facilitate their scholarly writing in terms of learning materials and references. In fact, academic writing courses were offered and made compulsory to assist them in writing effectively. However, the respondents felt that the courses were too generic that they did not cater to the students' individual needs. The courses also did not provide the students with the skills that they would need to write in their discipline.

Another external factor hampering the respondents' writing was the insufficient guidance from the instructors. 42 or $84 \%$ of the respondents claimed that the instructors mostly focused only on the content of their writing rather than the academic writing skills. Thus, although sufficient advice was given on the essential contents to be added, the article itself might not be 'scholarly' because guidance towards proper way of presenting the contents was not given.

Cultural aspect can also exert its influence on the writing. As writing is a reflection of the way we view things, which is often molded by our culture, an EFL writer may write differently from the native writer. For high-context cultures like the Eastern ones, putting forward a claim or an argument may not be straightforward. The data from the survey indicate that most of the respondents ( 42 or $84 \%$ ) were not sure how to write arguments in a clear and logical way, which is the way native speakers think and write. In fact, during the interview the respondents admitted that they did not really know what it meant by logical. For them an argument could be logic when it contained explanation. They were not aware of the types or reasoning than can be used to prove the logic and validity of claims.

The findings also indicate that 46 or $92 \%$ of the respondents faced problems in the critical thinking aspects in their writing which included lack of critical analysis and critical evaluation of the topic they wrote. Such problem is common among Asian EFL learners as the aspect of critical thinking is not really dealt with in learning. Thus, students from this part of the world usually would have problems in assessing arguments, ideas, claims or assumptions, and also in comparing the strengths and weaknesses of different perspectives. This is in line with Samanhudi and Linse's (2019) study on the Indonesian postgraduate students' challenges to academic writing in the UK. They found that the students encountered problems in their essay writing due to the lack of critical awareness, lack of understanding of the critical thinking concept and differences of academic requirements between Indonesian and British context.

\section{Psychological Factors}

The major psychological factors that usually interfere in the writing process are motivation, selfesteem and anxiety. In this study, these factors contributed largely towards the participants' problems in their writing. The data indicate that as many as 40 (80\%) of the respondents agreed that it was very important for them to write in English. Since English is a global language, their writings would be read worldwide if they were published in English. However, the data show that nearly half of the respondents had low motivation in writing in English due to their poor mastery of English and attitude towards writing itself. They students claimed that writing in English was difficult and required a long process to get it right. In the interview session, one student even 
said that he always felt frustrated when he had to make corrections after corrections. This became off-putting as the process of correcting recurred. Other participants claimed that the major obstacle in writing was they simply did not like writing regardless what language they had to use.

The hindrance to motivation in writing was also related to the participants' self-esteem. 24 (48\%) of the respondents claimed that they did not have motivations to write because they felt that they could not achieve the standards that were expected of them. They admitted that they needed to improve their English in order to also improve their writing skills. The respondents strongly felt that they did not have the confidence to write the whole article in English on their own. In the interview, the participants suggested having collaborative effort, especially with the lecturers who could check their language and content, in writing scholarly journals. This concurs with Westwood's (2004) findings that many students lack motivation and have difficulty in thinking hard to actively participate in writing assignments. They also tend to lack confidence because of unsatisfactory results and achievements.

Low self-esteem of the participants also led to their writing anxiety. The data demonstrate that the participants' anxiety were rooted in their linguistic incapability (mean=4.32), low selfconfidence (mean=4.10), lack of topical knowledge (mean=3.94), insufficient writing practice (mean=3.74), and fear of evaluation by the lecturers (mean=3.65). Other causes that contribute to the anxiety include the insufficient time given to complete the task (mean=3.54). The interview data relate this anxiety to respondents' delay or avoidance of the writing tasks. Similar findings were also reported by Rezaei and Jafari (2014) and Ningsih (2015) who found that teacher' negative feedback, low self-confidence, poor linguistic knowledge, time pressure and insufficient writing practice as the contributors to writing anxiety among EFL students in Iran and Indonesia respectively.

\section{Support Needed by EFL Students in Writing Scholarly Article}

The data from the survey and interview have provided rich understanding on the problems faced by the participants in their scholarly writing experience. The participants also gave their views on the kind of support needed to assist them in producing good scholarly article. This includes institutional support, pedagogical and social support.

In terms of institutional support, all of the participants felt that it may be helpful if a support centre for academic writing is established. Here, facilities like better access to the internet, and open access to more international journals and academic writings can be provided. Having resident writing instructors who can give personal advice and guidance towards good writing can also be beneficial to the students.

In addition, the participants strongly suggested that the institution provide specific workshops for specific fields of study. Usually, the workshops or courses given are generic and on one-off basis. It may help the students if the workshop is run on a long term so that the progress and the output of the writings can be monitored. 
Pedagogically, 42 or $84 \%$ of the participants felt that the guidance provided by the lecturers had not been sufficient in terms of time, teaching approach and writing model. The participants suggested introducing the academic writing courses earlier and students be developed with proper skills of writing. In addition, they also need strong mentoring from the instructors and supervisors in producing the articles. They need advice and guidance on the mechanics of scholarly writing like paraphrasing and critical evaluation, besides the content. In addition, they also suggested a smaller instructor-student ratio in a writing class/course so that more personal attention can be given to each student.

The findings have shown that the participants experienced anxiety in writing. This may be countered by providing social support for the students. Most of the participants enjoyed collaborative writing as it is less burdening, thus, less stressful. Hence, instructors should consider introducing the collaborative writing approach where the students can work together and support each other. In this way, the level of anxiety can be reduced, and the level of motivation and self-esteem can be raised.

\section{Conclusion}

In the world of academic, scholarly writing has always been very important as this credential in higher education is important (Al Badi, 2015). For this reason, publishing a scholarly article in English has been made mandatory as a pre-requisite to graduating in Indonesia. However, writing a scholarly article is one of the greatest challenges to EFL learners as it requires a wide range of linguistic, cognitive, and socio-cultural competences (Barkaoui, 2007).

This study has looked into the problems faced by the EFL post-graduate students in writing scholarly articles. It concurs with the previous studies that scholarly writing proves to be difficult for the EFL students. This study draws out pedagogical implications on academic writing as suggested by the overwhelming difficulties faced by the students in completing the task. The framework used to investigate the problem indicates that the students were not able to perform well in the task due to their lack of cognitive and linguistic skills, as well as psychological and external interferences. Thus, instructors, in structuring or planning their lessons on academic writing, should take into account these aspects that have proven to cause difficulties in accomplishing the task among the students. This approach may be more meaningful and beneficial rather than assessing students' writing problems based on the output as most empirical research had focused on.

The study is also significant as it informs the support needed by the students to assist them in producing good, quality scholarly writings. The data has objectively shown from the students' point of view the support needed from the institutional, pedagogical and social perspectives. These supports combined together, can host students, instructors and institutions to solve the problems in writing scholarly articles. 
INTERNATIONAL JOURNAL OF ACADEMIC RESEARCH IN PROGRESSIVE EDUCATION AND

DEVELOPMENT

Vol. 9, No. 4, 2020, E-ISSN: $2226-6348 @ 2020$ HRMARS

\section{References}

Abdulkareem, M. N. (2013). An investigation study of academic writing problems faced by Arab postgraduate Students at Universiti Teknologi Malaysia (UTM). Theory and Practice in Language Studies, 3 (9), 1552-1557.

Akbari, Z. (2015). Current challenges in teaching/learning English for EFL learners: The case of Junior High School and High School. Procedia - Social and Behavioral Sciences, 199 (3), 394401.

Alfaki, I. (2015). University students' English writing problems: diagnosis and remedy. International Journal of English Language Teaching, 3 (2), 40-52.

Al Badi, I. (2015). Academic writing difficulties of ESL learners. 2015 WEI International Academic Conference Proceedings. Spain, Barcelona, 65-78.

Al Fadda, H. (2012). Difficulties in academic writing: from the perspective of King Saud University postgraduate students. English Language Teaching, 5 (3). 123-130.

Al-Khasawneh, F. (2010). Writing for academic purposes: problems faced by Arab postgraduate students of the college of Business, UUM. ESP World, 9 (2), 1-23.

Al Mubarak, A. A. (2017). An investigation of academic writing problems level faced by undergraduate students at Al Imam Al Mahdi University- Sudan. English Review: Journal of English Education, 5(2), 175-188.

Al Seyabi, F., \& Tuzlukova, V. (2014). Writing problems and strategies: An investigative study in the Omani school and university context. Asian Journal of Social Sciences \& Humanities, $3(4), 37-48$.

Al-Zubeiry, H. (2020). Coherence problems in the English writings of Saudi University Students. Journal of Language Sciences and Literature, 25, 408-431.

Ankawi, A. (2015). The academic writing challenges faced by Saudi students studying in New Zealand [unpublished master's thesis]. Auckland University of Technology, New Zealand.

Ariyanti, A. (2016). Shaping students' writing: The study of fundamental aspects in mastering academic writing. Indonesian Journal of EFL and Linguistics, 1(11), 2503-4197.

Ariyanti, A., \& Fitriana, R. (2017). EFL students' difficulties and needs in essay writing. Advances in Social Science, Education and Humanities Research (ASSEHR), 158, 111-121.

Younes, B. Z., \& Albalawi, S. F. (2015). Exploring the most common types of writing problems among English language and translation major sophomore female students at Tabuk University. Asian Journal of Basic and Applied Sciences, 3(2), 7-26.

Barkaoui, K. (2007). Teaching writing to second language learners: Insights from theory and research. TESL Reporter 40 (1), 35-48.

Faradhibah, R. N. (2017) Analyzing students difficulties in maintaining their coherence and cohesion in writing process. [Undergraduate (S1) thesis]. Universitas Islam Negeri Alauddin Makassar.

Glatthorn, A. A. (1998). Writing the winning dissertation: A step-by-step guide. Thousand Oaks, CA: Corwin Press, Inc

Graddol, D. (2006). English next. London, UK: The British Council.

Hammad, E. A. (2016). Palestinian university students' problems with EFL essay writing in an instructional setting. In Teaching EFL writing in the 21st century Arab world. (pp. 99-124). Palgrave Macmillan UK. 
INTERNATIONAL JOURNAL OF ACADEMIC RESEARCH IN PROGRESSIVE EDUCATION AND

DEVELOPMENT

Vol. 9, No. 4, 2020, E-ISSN: $2226-6348 @ 2020$ HRMARS

Huwari, I. F., \& Al-Khasawneh, F. M. (2013). The reasons behind the weaknesses of writing in English among pre-year students' at Taibah University. English for Specific Purposes World, 14 (38), 1-9.

Jabali, O. (2018). Students' attitudes towards EFL university writing: A case study at An-Najah National University, Palestine. Heliyon, 4(11), 1-25.

Jafari, N., \& Ansari, D. N. (2012). The effect of collaboration on Iranian EFL learners' writing accuracy. International Education Studies, 5, (2), 125-131.

Khan, I. (2011). Learning difficulties in English: Diagnosis and pedagogy in Saudi Arabia. Educational Research (International Research Journal), 2(7), 1248-1257.

Khuwaileh, A., \& Al- Shoumali, A. (2000). Writing Errors: A Study of the Writing Ability of Arab Learners of Academic English and Arabic at University. Language Culture and Curriculum. 13(2), 174-183.

Manjet, K. (2016). An emic perspective on academic writing difficulties among international graduate students in Malaysia. GEMA Online: Journal of Language Studies, 16(3), 83-97.

Mustaque, S. (2014). Writing problems among the tertiary level students in Bangladesh: A study in Chittagong Region. Language in India, 14(1).

Ningsih, T. A. (2015). The study of foreign language writing anxiety among English Department students of Faculty of Letters, Jember University. [Unpublished undergraduate thesis]. Universitas Jember Indonesia.

Nolan, R., \& Rocco, T. (2009). Teaching graduate students in the social sciences writing for publication. International Journal of Teaching and Learning in Higher Education, 20 (2), 267273.

Padmadewi, N. N. (2016). Keterampilan menulis wacana argumentasi berbahasa Inggris dengan metode ESA (Engage, Study, Active) pada Mahasiswa level post intermediete di STIE Tratmia Mulya. LINGUITIKA, 23(44).

Rao, V. C. (2018). The use of English language in research. Journal for Research Scholars and Professionals of English Language Teaching. 8(2), 1-8.

Rezaei, M., \& Jafari, M. (2014). Investigating the levels, types, and the cause of writing anxiety among Iranian EFL students: A mixed method design. Procedia-Social and Behaviour Sciences, 98: 1547.

Samanhudi, U., \& Linse, C. (2019). Critical thinking-related challenges to academic writing: A case of Indonesian postgraduate students at a UK University. Lingua Cultura, 13 (2), 107-114.

Westwood, P. (2004). Learning and learning difficulties. University of Hong Kong: ACER Press.

Wigati, F. A. (2015). Kesulitan pada aspek-aspek writing mahasiswa dengan English proficiency levels yang berbeda. Jurnal IImiah Solusi, 1(3), 46-61.

Yaqin, M. A. (2015). Faktor penyebab rendahnya penggunaan referensi berbahasa Inggris dalam penulisan skripsi ilmu perpustakaan. FIHRIS, 10(2), 105-126.

Yuen, C. K., \& Mussa, I. H. (2015). Academic writing difficulties of Iraqi postgraduate students in Malaysia. International Journal of Education and Research, 3(6), 25-34.

Glatthorn, A. A. (1998). Writing the winning dissertation: A step-by-step guide. Thousand Oaks,

CA: Corwin Press, Inc 